\title{
The dilution effect in a freshwater mutualism: impacts of introduced host species on native symbionts
}

\author{
${\text { Robert } \text { Creed }^{1} \text {, Gretchen L. Bailey }}^{1}$, James Skelton ${ }^{2}$, and Bryan L. Brown ${ }^{3}$ \\ ${ }^{1}$ Appalachian State University \\ ${ }^{2}$ William \& Mary Department of Biology \\ ${ }^{3}$ Department of Biological Sciences Virginia Tech Blacksburg VA 24061 USA
}

September 27, 2021

\begin{abstract}
The dilution effect was originally proposed to describe the negative effect of increased host diversity on parasite abundance; with greater host diversity, parasite levels per host are predicted to be lower due to a higher probability of dispersing parasites encountering non-competent hosts. Dilution effects could also occur in many mutualisms if dispersing symbionts encounter hosts that vary in their competency. The introduction of non-native hosts can change community competency of a local group of host species. Crayfish introductions are occurring world-wide and these introductions are likely disrupting native crayfishsymbiont systems. Branchiobdellidan symbionts declined on native Cambarus crayfish occurring in the presence and absence of non-native Faxonius crayfish in the New River, USA. We performed an experiment investigating the effect of host density (1 vs 2 native hosts) and host diversity ( 1 native host and 1 introduced host) on branchiobdellidan abundance. The introduced $F$. cristavarius is a non-competent host for these worms. Six C. ingens were stocked on a C. chasmodactylus in each treatment and worm numbers were followed over 34 days. Worm numbers decreased over time on C. chasmodactylus alone and in the treatment in which a $C$. chasmodactylus was paired with an F. cristavarius. Worm numbers remained highest in the $2 C$. chasmodactylus treatment. There was no significant effect of host diversity on worm reproduction. Crayfish invasions may have negative effects on mutualistic symbionts depending on the competence of introduced hosts. Loss of native symbionts is one of the potential hidden, negative effects of invasions on native freshwater diversity.
\end{abstract}

\section{Hosted file}

Dilution effects in a freshwater mutualism.submitted.docx available at https://authorea.com/ users/436665/articles/538830-the-dilution-effect-in-a-freshwater-mutualism-impacts-ofintroduced-host-species-on-native-symbionts

\section{Hosted file}

Figure 1.docx available at https://authorea.com/users/436665/articles/538830-the-dilutioneffect-in-a-freshwater-mutualism-impacts-of-introduced-host-species-on-native-symbionts

\section{Hosted file}

Figure 2.docx available at https://authorea.com/users/436665/articles/538830-the-dilutioneffect-in-a-freshwater-mutualism-impacts-of-introduced-host-species-on-native-symbionts

\section{Hosted file}

Figure 3.docx available at https://authorea.com/users/436665/articles/538830-the-dilutioneffect-in-a-freshwater-mutualism-impacts-of-introduced-host-species-on-native-symbionts 


\section{Hosted file}

Figure 4.docx available at https://authorea.com/users/436665/articles/538830-the-dilutioneffect-in-a-freshwater-mutualism-impacts-of-introduced-host-species-on-native-symbionts 